\title{
Proteomic Analysis of Apoptosis Induced by Xanthoangelol, a Major Constituent of Angelica keiskei, in Neuroblastoma
}

\author{
Kou Motani, ${ }^{a}$ Keiichi Tabata, ${ }^{a}$ Yumiko Kimura, ${ }^{b}$ Soichiro Okano, ${ }^{c}$ Yasuko Shibata, ${ }^{c}$ \\ Yoshimitsu AвIKo, ${ }^{c}$ Hisashi NAGAI ${ }^{d}$ Toshihiro AkIHISA, ${ }^{d}$ and Takashi SuzUKI ${ }^{*, a, e}$ \\ ${ }^{a}$ Research Unit of Clinical Medicine, College of Pharmacy, Nihon University; ${ }^{b}$ Research Unit of Analytical Chemistry of \\ Pharmaceuticals, College of Pharmacy, Nihon University; 7-7-1 Narashinodai, Funabashi, Chiba 274-8555, Japan: \\ ${ }^{c}$ Department of Biochemistry and Molecular Biology, School of Dentistry at Matsudo, Nihon University; 2-870-1 \\ Sakaecho-nishi, Matsudo, Chiba 271-8587, Japan: ${ }^{d}$ Department of Materials and Applied Chemistry, College of Science \\ and Technology, Nihon University; 1-8 Kanda Surugadai, Chiyoda-ku, Tokyo 101-8301, Japan: and ${ }^{e}$ Department of \\ Pediatrics and Child Health, School of Medicine, Nihon University; 30-1 Oyaguchikami-cho, Itabashi-ku, Tokyo \\ 173-0032, Japan. $\quad$ Received November 27, 2007; accepted January 28, 2008; published online January 29, 2008
}

Neuroblastoma is the most common solid tumor in children. Despite aggressive chemotherapy, the prognosis of patients with advanced neuroblastoma is still very poor. Our recent study showed that xanthoangelol, a major chalcone constituent of the stem exudates of Angelica keiskei, induced caspase-3-dependent apoptosis in neuroblastoma cells. However, details of the mechanism underlying its apoptotic action are still unclear. Here we show that xanthoangelol triggers oxidative stress by generation of reactive oxygen species and induces apoptosis through release of cytochrome $c$ and activation of caspase-9 in IMR-32 cells. Pretreatment with an antioxidant, vitamin E, prevented the increase of reactive oxygen species and apoptosis induced by xanthoangelol. Proteomic analysis using 2-dimensional electrophoresis and MALDI-TOF-MS revealed that DJ-1 protein was involved in xanthoangelol-induced apoptosis. DJ-1 responded to its oxidative stress status by being oxidized itself. Furthermore, DJ-1 was down-regulated by xanthoangelol, leading to loss of antioxidant function and acceleration of apoptosis. We also show that xanthoangelol has a cytotoxic effect on drug-resistant LA-N-1 and NB-39 cells as well as drug-sensitive IMR-32 and SK-N-SH cells. These findings suggest that xanthoangelol induces apoptosis by increasing reactive oxygen species and targeting DJ-1, and such mechanism may be an effective therapeutic approach for advanced neuroblastoma.

Key words xanthoangelol; apoptosis; oxidative stress; neuroblastoma; proteomics

Neuroblastoma is the most common extracranial solid tumor in children and is derived from cells of the sympathetic nervous system. Its clinical behavior varies according to patient age at diagnosis. In patients over 1 year of age, the tumor is very aggressive and drug-resistant. The 5-year survival rate of patients with such advanced tumors is only 25 $30 \%$, despite aggressive chemotherapy. Conversely, in patients under 1 year of age, the tumor usually has a favorable prognosis and frequently regresses or differentiates into ganglioneuroma, requiring little or no therapy. Even after extensive metastasis, some neuroblastomas undergo spontaneous regression (special stage 4s). Although the precise mechanism responsible for this clinical heterogeneity remains unclear, some reports suggest that apoptosis plays a role. In neuroblastomas showing spontaneous regression, extensive apoptosis occurs. ${ }^{1,2)}$ On the other hand, disruption of the apoptosis machinery is observed in drug-resistant and/or advanced neuroblastomas, e.g., expression of $\mathrm{Bcl}-2,{ }^{3)}$ p53 mutation or lack of p53 function ${ }^{4)}$ and loss of caspase- 8 expression. ${ }^{5)}$ Therefore, novel drugs that induce apoptosis in advanced neuroblastoma are required.

Angelica keiskei (Ashitaba in Japanese) is a medicinal plant that grows mainly along the Pacific coast of Japan. It has been used traditionally as a diuretic, laxative, analeptic and galactagogue, and has recently gained attention as a health food. Various compounds, such as chalcones, coumarins and flavanones, have already been isolated from Angelica keiskei. ${ }^{6}$ Xanthoangelol, a representative chalcone constituent, has been shown to have various biological activi- ties, including antibacterial activity, gastric $\mathrm{H}^{+}, \mathrm{K}^{+}$-ATPase inhibition, and anti-vasoconstriction. ${ }^{7-9)}$ Importantly, xanthoangelol shows anti-tumor-promoting activity in mouse skin carcinogenesis ${ }^{10)}$ and inhibits tumor growth and metastasis in tumor-bearing mice without causing body weight loss. ${ }^{11)}$ Our latest study showed that xanthoangelol had potent cytotoxicity and induced apoptosis with the involvement of caspase-3 activation in neuroblastoma. ${ }^{12)}$ However, details of the mechanism of xanthoangelol-induced apoptosis are still unclear.

Apoptosis occurs mainly through two pathways. In the death receptor pathway, receptor ligation leads to activation of caspase-8. In the mitochondrial pathway, on the other hand, various apoptosis-inducing triggers such as DNA damage and oxidative stress cause activation of caspase-9. In these two different pathways, activated initiators caspase- 8 and caspase-9 finally activate caspase-3, the downstream (executor) caspase. ${ }^{13)}$ The mitochondrial pathway is regulated by Bcl-2 family proteins, the pro-apoptotic Bax and the antiapoptotic Bcl-2. However, apoptosis is regulated more intricately by a large number of molecules. ${ }^{14)}$

Proteomic analysis using 2-dimensional electrophoresis (2-DE) and matrix assisted laser desorption ionization-time of flight (MALDI-TOF)-MS is a very useful tool for examining protein changes comprehensively before and after treatment with drugs. In the present study, we showed that xanthoangelol has a cytotoxic effect on drug-resistant neuroblastoma, and induces apoptosis of the tumor cells. We also investigated the mechanism of this xanthoangelol-induced apoptosis in neuroblastoma using proteomic analysis. 


\section{MATERIALS AND METHODS}

Cell Lines and Culture Conditions The neuroblastoma cell lines IMR-32, SK-N-SH, LA-N-1 (RIKEN cell bank) and NB-39 (kindly provided by Dr. Toshimitsu Suzuki, Fukushima Medical University) and the leukemia cell line Jurkat (RIKEN cell bank) were grown in RPMI 1640 medium (Invitrogen) supplemented with 10\% fetal bovine serum (Invitrogen), $100 \mathrm{U} / \mathrm{ml}$ penicillin (Invitrogen), and 100 $\mu \mathrm{g} / \mathrm{ml}$ streptomycin (Invitrogen). The cells were maintained at $37{ }^{\circ} \mathrm{C}$ in a $5 \% \mathrm{CO}_{2}$ atmosphere and high humidity.

Drugs and Antibodies Xanthoangelol ( $3^{\prime}$ - $C$-geranyl$2^{\prime}, 4,4^{\prime}$-trihydroxychalcone) was isolated from the stem exudate of Angelica keiskei ${ }^{6}$ ) and saved as a $50 \mathrm{~mm}$ stock solution in $100 \%$ dimethyl sulfoxide (DMSO) (final concentration of DMSO 0.2\%). Camptothecin and cisplatin were purchased from Wako and dissolved in DMSO (final concentration of DMSO $0.2 \%)$. ( \pm )- $\alpha$-Tocopherol (vitamin E; VE) was from Sigma and saved as a $100 \mathrm{~mm}$ stock solution in $100 \%$ ethanol (final concentration of ethanol 1\%). 2', $7^{\prime}$ Dichlorodihydrofluorescein diacetate $\left(\mathrm{H}_{2} \mathrm{DCFDA}\right)$ was from Molecular Probes and saved as a $100 \mathrm{~mm}$ stock solution in DMSO (final concentration of DMSO 0.05\%). 3-[4,5-Dimethylthiazol-2-yl]-2,5-diphenyltetrazolium bromide (MTT) and Hoechst 33342 were purchased from Sigma. Trypan blue was purchased from Wako. Anti-caspase-8 (clone: 1C12) and anti-caspase-9 were from Cell Signaling. Anti-cytochrome c was from BD Pharmingen. Anti-Tom20 (clone: 29) was from BD Transduction Laboratories. Anti-DJ-1 (clone: 3E8) was from Stressgen. Anti- $\beta$-tubulin (clone: TUB 2.1) and antimouse and anti-rabbit IgG secondary antibody were from Sigma.

MTT Assay MTT assay was performed as described previously. ${ }^{12)}$ Briefly, cells were treated with various concentrations of xanthoangelol, camptothecin, and cisplatin for $48 \mathrm{~h}$, and then MTT solution was added to the well. After incubation for $3 \mathrm{~h}$, the cells were lysed and the generated blue formazan were solubilized with isopropanol containing 0.04 $\mathrm{N} \mathrm{HCl}$ stop solution. The absorbance at $570 \mathrm{~nm}$ (peak) and $655 \mathrm{~nm}$ (bottom) was measured using a microplate reader (BIO-RAD).

Hoechst 33342 Staining Cells $\left(5 \times 10^{5}\right.$ or $1 \times 10^{6}$ cells $/ 2$ $\mathrm{ml})$ were seeded onto a 6-well plate with phenol red-free RPMI 1640 medium and treated with $10 \mu \mathrm{m}$ xanthoangelol for $0-24 \mathrm{~h}$. Hoechst 33342 nuclear dye was added to a final concentration $25 \mu \mathrm{g} / \mathrm{ml}$ at $30 \mathrm{~min}$ before the termination of xanthoangelol treatment. Morphological changes were observed by fluorescence microscopy (OLYMPUS). For examining the protective effect of VE, cells were pretreated with 1 $\mathrm{mm} \mathrm{VE}$ or vehicle (ethanol) for $3 \mathrm{~h}$ and then either treated with vehicle (DMSO) or treated with xanthoangelol for $24 \mathrm{~h}$.

Whole-Cell Extraction and Subcellular Fractionation Cells $\left(2 \times 10^{6}\right.$ or $5 \times 10^{6}$ cells $\left./ 5 \mathrm{ml}\right)$ were seeded onto a $60 \mathrm{~mm}$ dish and treated with 10 or $100 \mu \mathrm{m}$ xanthoangelol. For isolation of whole-cell lysates, cells were collected and washed with Tris buffered saline (TBS) and lysed in extraction buffer containing $20 \mathrm{~mm}$ Tris- $\mathrm{HCl}(\mathrm{pH} 8.0), 137 \mathrm{~mm} \mathrm{NaCl}, 1 \%$ NP-40, $10 \%$ glycerol, protease inhibitor cocktail I $(1: 200$; Sigma), phosphatase inhibitor cocktail II (1:100; Sigma), 1 $\mathrm{mm}$ phenylmethylsulfonyl fluoride (PMSF) and $1 \mathrm{~mm}$ dithiothreitol (DTT). The cells were disrupted by sonication for
$30 \mathrm{~s}$ twice, and the supernatants were obtained by centrifugation at $9000 \times \boldsymbol{g}$ for $10 \mathrm{~min}$ at $0{ }^{\circ} \mathrm{C}$. For isolation of the cytosolic and mitochondria-rich fractions, cells were collected and washed with TBS and suspended in buffer A $(20 \mathrm{~mm}$ HEPES-KOH ( $\mathrm{pH} 7.5$ ), $10 \mathrm{~mm} \mathrm{KCl}, 1.5 \mathrm{~mm} \mathrm{MgCl}_{2}, 1 \mathrm{~mm}$ sodium EDTA, $250 \mathrm{~mm}$ sucrose, protease inhibitor cocktail I $(1: 200)$, phosphatase inhibitor cocktail II $(1: 100), 1 \mathrm{~mm}$ PMSF and $1 \mathrm{~mm}$ DTT) containing $0.05 \%$ digitonin. After incubation for $20 \mathrm{~min}$ on ice, the cell suspensions were centrifuged at $15000 \times \boldsymbol{g}$ for $20 \mathrm{~min}$ at $4{ }^{\circ} \mathrm{C}$. The supernatants were saved as a cytosolic fraction, and the pellets were further resuspended in buffer A containing 1\% NP-40 and sonicated for $30 \mathrm{~s}$ twice. After $20 \mathrm{~min}$ on ice, the supernatants were obtained as a mitochondria-rich fraction by centrifugation at $9000 \times \mathbf{g}$ for $10 \mathrm{~min}$ at $0{ }^{\circ} \mathrm{C}$.

Western Blotting Western blotting was performed as described previously. ${ }^{12)}$ Briefly, either whole-cell lysates or cytosolic and mitochondria-rich fractions were mixed with $3 \times$ sample buffer $(0.24 \mathrm{~m}$ Tris- $\mathrm{HCl}$ ( $\mathrm{pH} 6.8), 9 \%$ sodium dodecyl sulfate (SDS), 30\% glycerol, 15\% 2-mercaptoethanol and trace of bromophenol blue (BPB)) at 2:1. Equal amounts of proteins were separated by SDS-polyacrylamide gel electrophoresis (SDS-PAGE) and transferred to polyvinylidene fluoride membranes (GE Healthcare). After blocking, the membranes were probed with antibodies, and the blots were detected with an enhanced chemiluminescence (ECL) system (GE Healthcare).

Proteomics Cells $\left(5 \times 10^{6}\right.$ cells $\left./ 5 \mathrm{ml}\right)$ were seeded onto a 60-mm dish and treated with $100 \mu \mathrm{m}$ xanthoangelol, or left untreated, for $1 \mathrm{~h}$. For preparing protein samples, cells from 6 dishes per group were collected into one tube, washed with TBS, and lysed in lysis buffer containing $7 \mathrm{M}$ urea, $2 \mathrm{M}$ thiourea, $4 \%$ CHAPS, $0.5 \%$ Triton X-100 and $0.5 \%$ IPGbuffer (GE Healthcare). The protein samples were diluted with rehydration buffer ( $7 \mathrm{~m}$ urea, $2 \mathrm{~m}$ thiourea, $2 \%$ CHAPS, $0.5 \%$ Triton X-100, $0.5 \%$ IPG-buffer and trace of BPB) at $1: 9$. The diluted sample solutions were loaded onto Immobiline ${ }^{\mathrm{TM}}$ DryStrips (pH 3-10, $11 \mathrm{~cm}$; GE Healthcare) through rehydration overnight at room temperature. After rehydration, isoelectric focusing was started at $300 \mathrm{~V}$ and the voltage was gradually increased to $3500 \mathrm{~V}$ for $2.5 \mathrm{~h}$ and further held at $3500 \mathrm{~V}$ for $5 \mathrm{~h}$ using a Multiphor II electrophoresis system (GE Healthcare). The strips were equilibrated in initial equilibration buffer containing $1 \%$ DTT, $50 \mathrm{~mm}$ Tris- $\mathrm{HCl}(\mathrm{pH} 8.8$ ), $6 \mathrm{~m}$ urea, $30 \%$ glycerol, $2 \% \mathrm{SDS}$ and trace BPB for $15 \mathrm{~min}$ and a second equilibration buffer containing $2.5 \%$ iodoacetamide, $50 \mathrm{~mm}$ Tris- $\mathrm{HCl}(\mathrm{pH} 8.8), 6 \mathrm{~m}$ urea, $30 \%$ glycerol, $2 \%$ SDS and trace of BPB for $15 \mathrm{~min}$. The second-dimension electrophoresis was conducted on $12.5 \%$ SDS-polyacrylamide gel at $300 \mathrm{~V}$ at $4{ }^{\circ} \mathrm{C}$. Gels were stained with $0.1 \%$ Coomassie Brilliant Blue (CBB) R-350 (GE Healthcare) solution overnight at room temperature. After washing away the excess dye with $30 \%$ methanol $/ 10 \%$ acetic acid solution, the gels were scanned with an Image Scanner (GE Healthcare). The spots were analyzed by Image Master 2D Platinum ver. 5.0 software (GE Healthcare) according to the manufacturer's protocol. To normalize spot volumes, the volume of each spot was divided by the total volume of all the spots in the gel. For the experiment to examine the isoelectric point (pI) shift of DJ-1, after isoelectric focusing of a strip (pH $4-7,13 \mathrm{~cm}$ ), SDS-PAGE and im- 
munoblotting were performed as described in "Western blotting" above. In-gel digestion, MALDI-TOF-MS analysis and protein identification were performed as described previously. ${ }^{15)}$ Preliminary amino acid sequences for human open reading frame (ORF) data were obtained from NCBI.

Stealth RNAi Treatment IMR- 32 cells $\left(2.5 \times 10^{5}\right.$ cells $/ 3$ $\mathrm{ml}$ ) were transfected by $20 \mathrm{~nm}$ of Stealth RNAi PARK7(DJ1)-HSS117568 (Invitrogen) or Stealth RNAi negative control LO GC (Invitrogen) using lipofectamine RNAiMAX (Invitrogen) according to the supplier's manual. Following RNAi treatment for $24 \mathrm{~h}$, (a) cells were harvested and assessed for total DJ-1 content by Western blotting with anti-DJ-1 antibody, (b) $\mathrm{H}_{2} \mathrm{O}_{2}$ (final concentration: $0-50 \mu \mathrm{M}$ ) was added to the cell culture medium and cell viability was analyzed with trypan blue exclusion assay (as described below) at $24 \mathrm{~h}$ after exposure.

Reactive Oxygen Species (ROS) Detection Cells were seeded onto 96 -well $\left(5 \times 10^{4}\right.$ or $1 \times 10^{5}$ cells $/ 100 \mu$ l) or 6 -well $\left(1 \times 10^{6}\right.$ cells $\left./ 2 \mathrm{ml}\right)$ plates with phenol red-free RPMI 1640 medium, and incubated with $50 \mu \mathrm{M} \mathrm{H}_{2}$ DCFDA, an indicator of ROS, for $30 \mathrm{~min}$. This was followed by treatment with 10 or $100 \mu \mathrm{M}$ xanthoangelol, or DMSO for 5-120 min. ROS generation was detected by a fluorescence microplate reader (excitation $485 \mathrm{~nm}$, emission $520 \mathrm{~nm}$ ) (BMG LABTECH). For detection of intracellular ROS, cells were treated with 10 $\mu \mathrm{M}$ xanthoangelol or DMSO for $2 \mathrm{~h} . \mathrm{H}_{2}$ DCFDA was added at $30 \mathrm{~min}$ before the end of xanthoangelol treatment. Intracellular ROS was observed by fluorescence microscopy. For examining the preventive effect of VE, cells were pretreated with $1 \mathrm{~mm}$ VE or ethanol for $3 \mathrm{~h}$ and then treated with $10 \mu \mathrm{M}$ xanthoangelol or DMSO for $2 \mathrm{~h} . \mathrm{H}_{2}$ DCFDA was added at 30 min before the termination of xanthoangelol treatment.

Trypan Blue Exclusion Assay Trypan blue exclusion assay was performed as described previously. ${ }^{12)}$ Briefly, the cells $\left(1 \times 10^{6}\right.$ cells $\left./ 2 \mathrm{ml}\right)$ were pretreated with $1 \mathrm{~mm}$ VE or ethanol for $3 \mathrm{~h}$ and then treated with $10 \mu \mathrm{M}$ xanthoangelol or $10 \mu \mathrm{M}$ cisplatin, or DMSO for $24 \mathrm{~h}$ at $4{ }^{\circ} \mathrm{C}$. After addition of trypan blue solution (final concentration $0.5 \%$ ), the numbers of total and dead cells were counted by phase-contrast microscopy (OLYMPUS).

\section{RESULTS}

Cytotoxic Effect of Xanthoangelol on Chemoresistant Neuroblastoma We compared the effects of xanthoangelol (Fig. 1A) and the conventional chemotherapeutic agents, camptothecin and cisplatin, against neuroblastoma cells. MTT assay showed that IMR-32 and SK-N-SH cells were sensitive to camptothecin ( $\mathrm{IC}_{50} 2.6$ and $8.7 \mathrm{~nm}$, respectively) and cisplatin $\left(\mathrm{IC}_{50} 1.0\right.$ and $4.6 \mu \mathrm{M}$, respectively), whereas LA-N-1 and NB-39 cells were resistant to camptothecin $\left(\mathrm{IC}_{50}>100 \mu \mathrm{M}\right.$, both) and cisplatin $\left(\mathrm{IC}_{50} 83\right.$ and $85 \mu \mathrm{M}$, respectively) (Fig. 1B). In contrast, xanthoangelol had a cytotoxic effect on drug-resistant LA-N-1 and NB-39 cells $\left(\mathrm{IC}_{50}\right.$ 12 and $11 \mu \mathrm{M}$, respectively) as well as drug-sensitive IMR-32 and SK-N-SH cells ( $\mathrm{IC}_{50} 2.6$ and $14 \mu \mathrm{m}$, respectively) (Fig. 1B). These results suggest that xanthoangelol is effective for the treatment of chemoresistant neuroblastoma.

Induction of Apoptosis by Xanthoangelol through the Mitochondrial Pathway in Neuroblastoma Cells Xanthoangelol has been shown to induce apoptosis in neuroblas-
A

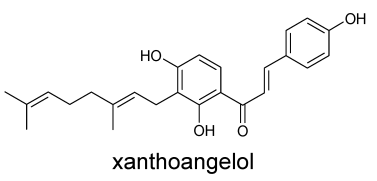

B
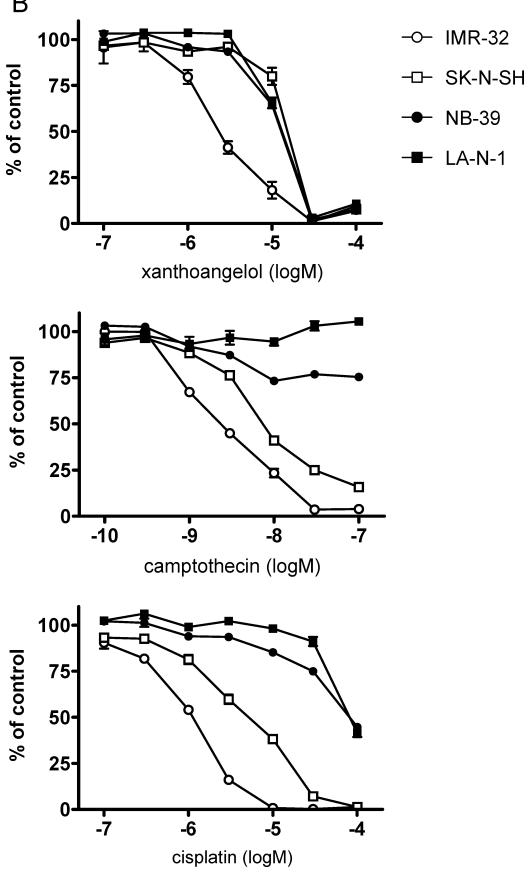

Fig. 1. Xanthoangelol Has Marked Cytotoxic Effect on ChemotherapyResistant Neuroblastoma Cells

(A) Structure of xanthoangelol. (B) Cell viability was measured by MTT assay. IMR-

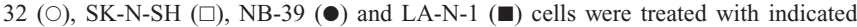
concentrations of xanthoangelol, camptothecin and cisplatin, or DMSO (vehicle control) for $48 \mathrm{~h}$. Each plot shows the survival rate relative to the vehicle control (mean \pm S.E.M.; $n=3$ ).

toma. ${ }^{12)}$ To confirm whether xanthoangelol induces apoptosis, we examined the nuclear morphology of IMR-32 cells exposed to $10 \mu \mathrm{M}$ xanthoangelol for $0-24 \mathrm{~h}$. Apoptotic cells characterized by nuclear condensation were observed in the cells $4 \mathrm{~h}$ after application (Fig. 2Ad), but not in control preparations (Fig. 2Ab). Most of the cells underwent apoptosis at $8 \mathrm{~h}$ after application (Fig. 2Af). Phase contrast microscopy showed that the cells became detached from the plates within $4 \mathrm{~h}$ after application of xanthoangelol, and became rounded (Fig. 2Ac) and shrunk (Fig. 2Ae), finally exhibiting cell blebbing (Fig. 2Ag) which are the morphological hallmarks of apoptosis. These results indicate that xanthoangelol induces apoptosis in IMR-32 cells.

Since it has been demonstrated that xanthoangelol induces apoptosis through caspase-3 activation, ${ }^{12)}$ we attempted to clarify which pathway - the death receptor or the mitochondrial pathway - was involved in xanthoangelol-induced apoptosis. It has been reported that pro-caspase- 8 is not expressed in advanced neuroblastoma. ${ }^{5}$ ) Therefore, we first examined the expression of pro-caspase- 8 protein in intact neuroblastoma cell lines (Jurkat was used as a positive control) by Western blotting. Absence of expression of pro-caspase- 8 was observed in IMR-32, SK-N-SH and LA-N-1 cells, and slight expression was observed in NB-39 cells in comparison with Jurkat cells (data not shown). Activation of caspase-8 did not occur in all neuroblastoma cell lines after application 
A

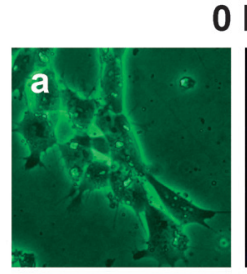

$\mathrm{Oh}$

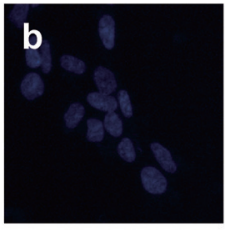

$8 \mathrm{~h}$
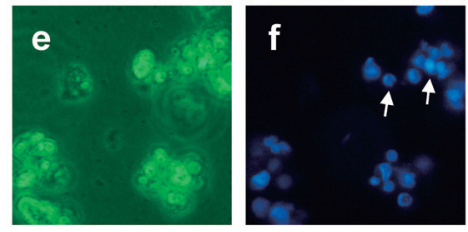

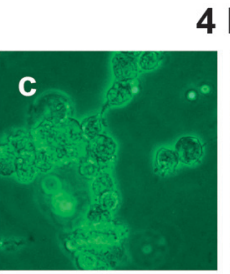

$4 \mathrm{~h}$

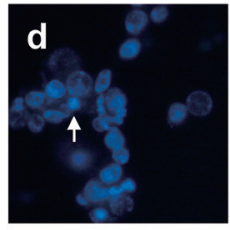

$24 \mathrm{~h}$

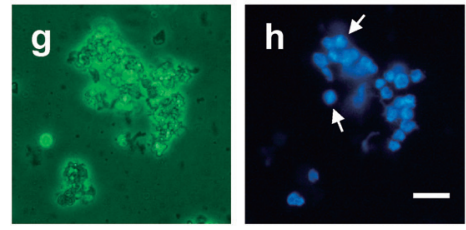

B
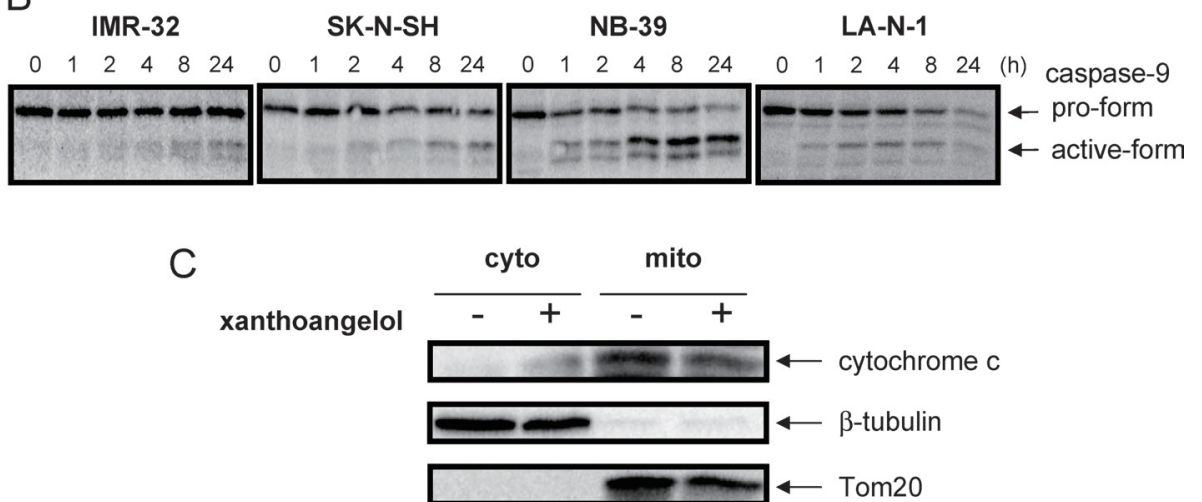

Fig. 2. Xanthoangelol Induces Apoptosis through Mitochondrial Pathway in Neuroblastoma Cells

(A) Nuclei of the cells were stained with Hoechst 33342. IMR-32 cells were treated with $10 \mu \mathrm{M}$ xanthoangelol for $0 \mathrm{~h}$ (non-treatment), $4 \mathrm{~h}, 8 \mathrm{~h}$ and $24 \mathrm{~h}$. Left panels show the phase contrast image (a, c, e and g) and right panels show the fluorescent image (b, d, f and h). Phase contrast and fluorescent images were obtained from the same view. Arrows in the panels indicate cells that have undergone nuclear condensation. Bar, $20 \mu \mathrm{m}$. (B) Western blotting analysis for caspase-9 activation. IMR-32, SK-N-SH, NB-39 and LA-N-1 cells were treated with $100 \mu \mathrm{m}$ xanthoangelol for $0-24 \mathrm{~h}$, and then pro- or active-caspase-9 was detected. (C) The expression of cytochrome $\mathrm{c}$ in cytosolic (cyto) and mitochondria-rich (mito) fractions was detected by Western blotting. IMR-32 cells were exposed to $10 \mu \mathrm{M}$ xanthoangelol or vehicle for $8 \mathrm{~h}$ and then cellular fractionation was performed. $\beta$-Tubulin and Tom-20 were used as the cytosolic and mitochondrial marker protein, respectively.

of $100 \mu \mathrm{M}$ xanthoangelol (data not shown). We next attempted to detect activation of caspase-9 in neuroblastoma cell lines exposed to $100 \mu \mathrm{M}$ xanthoangelol for $0-24 \mathrm{~h}$. Procaspase- 9 was cleaved and the level of active-caspase- 9 increased time-dependently in all neuroblastoma cell lines, being especially significant at 8 and $24 \mathrm{~h}$ (Fig. 2B). The activated caspase- 9 was also detected after $8-24 \mathrm{~h}$ treatment of $10 \mu \mathrm{M}$ xanthoangelol in IMR-32 (data not shown). Since activation of caspase- 9 occurs upon release of cytochrome c from mitochondria to the cytosol, ${ }^{13)}$ we tested cytochrome c release to the cytosolic fraction from the mitochondria-rich fraction. As shown in Fig. 2C, release of cytochrome c was observed after $8 \mathrm{~h}$ treatment with $10 \mu \mathrm{M}$ xanthoangelol, but not control in cytosolic fractions. These results suggest that the mitochondrial pathway plays a more important role in the mechanism of xanthoangelol-induced apoptosis than the death receptor pathway. In our previous study, however, it was shown that protein levels of Bax and Bcl-2 are not affected by xanthoangelol. ${ }^{12)}$ Thus, further study is required to clarify the mechanism leading to activation of the mitochondrial pathway.

Involvement of Oxidative Stress in Xanthoangelol-Induced Apoptosis as Indicated by Proteomic Analysis To elucidate the detailed mechanism of xanthoangelol-induced apoptosis, especially in the upstream phase of the caspase cascade, a protein sample was prepared from IMR-32 cells treated with $100 \mu \mathrm{m}$ xanthoangelol for $1 \mathrm{~h}$, a time point that is thought to precede caspase activation. Untreated samples, and samples treated with xanthoangelol, were subjected to 2$\mathrm{DE}$ ( $\mathrm{pH}$ range 3-10), which was performed five times per sample, and three gels were selected from each of the five gels. The two-DE map for xanthoangelol-treated cells was then compared with the map for non-treated cells (Fig. 3A). Two hundred fifteen protein spots in these gels were matched between the xanthoangelol-treated and non-treated groups. Among the 215 matching spots, 23 were changed by xanthoangelol in comparison to the control $(>1.5$ fold and $p<0.05$ by Student's $t$-test). Then, 16 of these spots were successfully identified by MALDI-TOF-MS. As shown in Fig. $3 \mathrm{~A}$ and Table 1, 7 spots were up-regulated and 9 were downregulated. Most of the proteins were involved in oxidative stress: DJ-1, peroxiredoxin 6, triosephosphate isomerase 1, glyceraldehyde-3-phosphate dehydrogenase, and phosphoglycerate mutase 1 ( 5 of 14 proteins). Among these oxidative stress-related proteins, the most changed protein was DJ-1, which showed a $37 \%$ reduction relative to the control (Fig. $3 \mathrm{~A}$, Table 1). These results imply that oxidative stress is involved in xanthoangelol-induced apoptosis. 


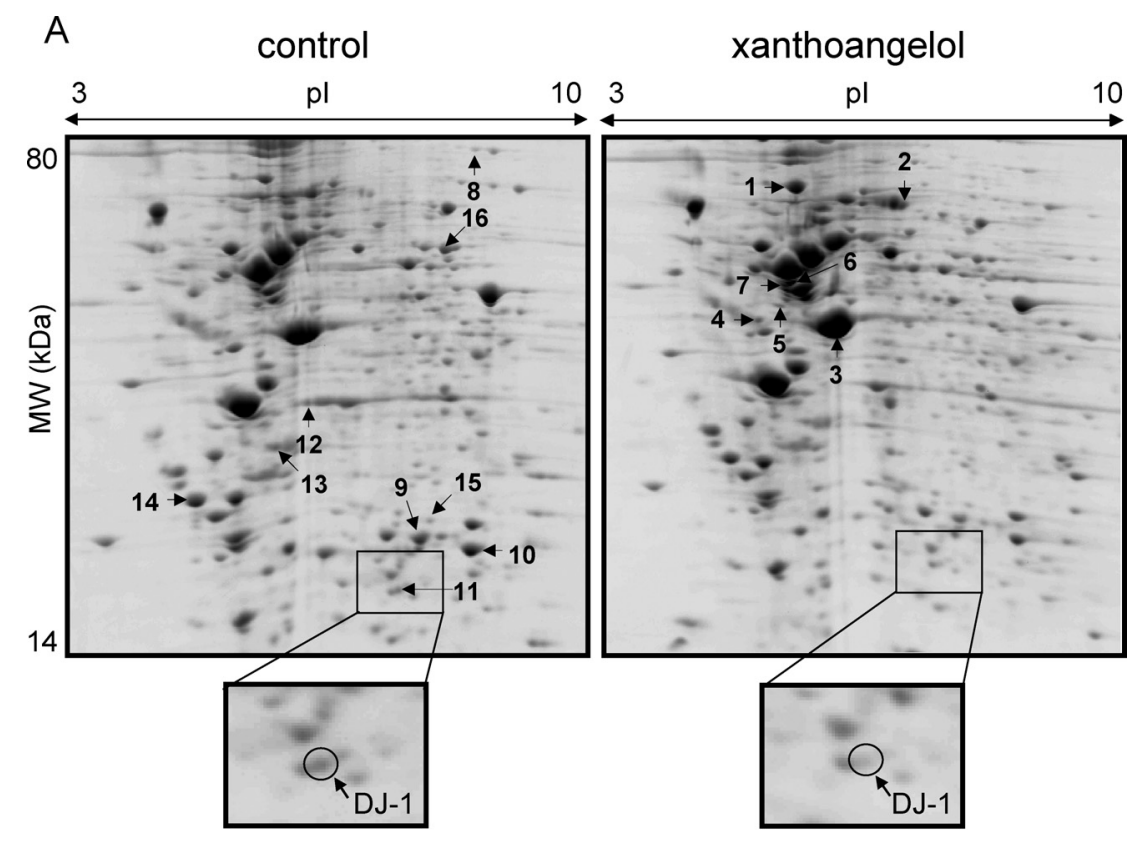

xanthoangelol
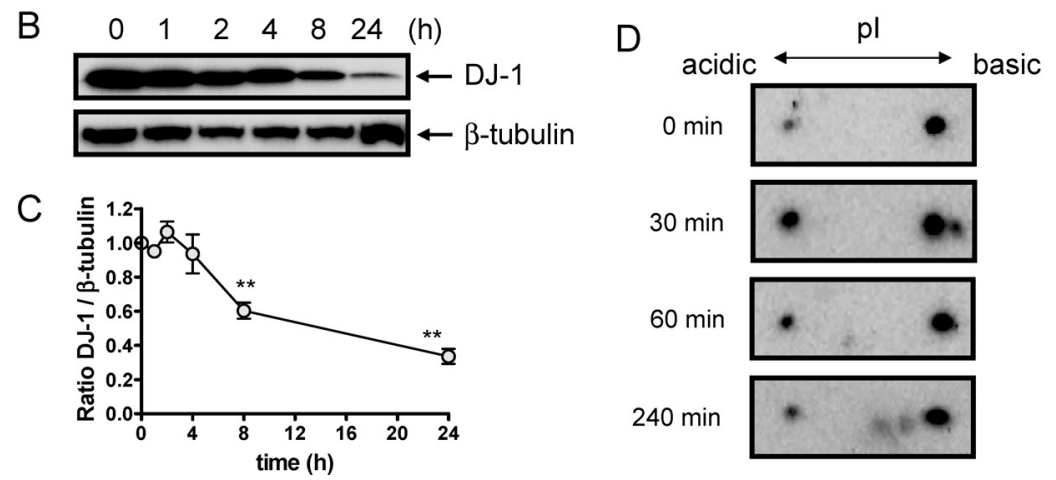

Fig. 3. Effect of Xanthoangelol on Total Amount and pI of DJ-1

(A) The two-DE map for xanthoangelol-treated cells. Proteins $(350 \mu \mathrm{g})$ from IMR-32 cells treated with $100 \mu \mathrm{M}$ xanthoangelol for $1 \mathrm{~h}$ (xanthoangelol) or untreated (control) were separated by pI (horizontal) and molecular weight (MW) (vertical), and stained with CBB solution. Arrows indicate spots that were up-regulated (No. 1-7) or down-regulated (No. 8-16) by xanthoangelol. DJ-1 spots are shown in detail. (B) DJ-1 bands detected by Western blotting are shown. IMR-32 cells were treated with $100 \mu \mathrm{M}$ xanthoangelol with $0-24 \mathrm{~h}$. The ratio DJ-1 to $\beta$-tubulin is shown in (C). Each plot is shown as mean \pm S.E.M.; $n=3$. $* * p<0.01 v s$. control $(0 \mathrm{~h})$ compared by one-way ANOVA followed by Bonferroni's post-hoc test. (D) Immunoblotting analysis for DJ-1 protein following 2-DE separation. IMR-32 cells were treated with $100 \mu \mathrm{M}$ xanthoangelol for $0-240$ min. The right and left spots indicate the reduced (basic) and oxidized (acidic) forms, respectively.

Xanthoangelol Triggers Oxidative Stress and DownRegulates DJ-1 To confirm the change of DJ-1 in the results of the 2-DE experiment, we performed Western blotting of SDS-PAGE-migrated proteins using anti-DJ-1 antibody. In this experiment, the level of DJ-1 was markedly reduced to $60 \%$ and $34 \%$ of the control value at $8 \mathrm{~h}$ and $24 \mathrm{~h}$ treatment of $100 \mu \mathrm{M}$ xanthoangelol, respectively (Figs. 3B, C). However, expression of DJ-1 did not change after $1 \mathrm{~h}$ of xanthoangelol treatment (Figs. 3B, C), inconsistent with the results of 2-DE. This discrepancy suggested that the change in the DJ-1 spot on 2-DE gels does not imply a change in the total amount, but rather a shift in pI. DJ-1 has been reported to show a pI shift from basic to acidic by being oxidized itself when cells are treated with oxidative stress inducers. $^{16-18)}$ Therefore, to examine whether the pI of DJ-1 was shifted by exposure of cells to $100 \mu \mathrm{M}$ xanthoangelol for 0 $240 \mathrm{~min}$, we performed 2-DE using strips within a $\mathrm{pH}$ range of 4-7 followed by Western blotting with anti-DJ-1 antibody. The $\mathrm{pI}$ of DJ-1 was shifted to acidic and the oxidized form was increased at $30 \mathrm{~min}$ (Fig. 3D). Thereafter, although the oxidized form was slightly decreased, the $\mathrm{pI}$ shift of DJ-1 was still maintained at $60 \mathrm{~min}$ (Fig. 3D). The decreased amount of the DJ-1 protein spot on 2-DE gels can probably be explained by a shift of $\mathrm{pI}$ from basic to acidic. These results suggest that DJ-1 acts as a sensor for xanthoangelol-induced oxidative stress, and moreover that xanthoangelol down-regulates the total amount of DJ-1.

To determine whether DJ-1 plays a key role in the protection of cells from oxidative stress in the neuroblastoma cell line, cell viability in response to oxidative stress was compared between DJ-1-knocked down IMR-32 cells and negative control cells using Stealth RNAi. Although DJ-1 protein down-regulation was not absolute, DJ-1-knocked down IMR32 cells were shown to be more sensitive to $\mathrm{H}_{2} \mathrm{O}_{2}$ than the negative control in trypan blue exclusion assay (Fig. 4). These data indicate that down-regulation of DJ-1 by xanthoangelol is responsible for the cell death triggered by oxidative stress in neuroblastoma cells.

Essential Role of Oxidative Stress in Apoptosis Induction by Xanthoangelol Oxidative stress occurs when the 
Table 1. Proteins Up- or Down-Regulated by Xanthoangelol in Proteomic Analysis

Up-regulated proteins

\begin{tabular}{|c|c|c|c|c|}
\hline Spot No. ${ }^{a)}$ & Protein name $e^{b)}$ & MW (Da) & $\mathrm{pI}$ & $\begin{array}{l}\text { Ratio of spot volume } \\
\text { (xanthoangelol/control) }\end{array}$ \\
\hline 1 & GRP78/BiP & 72402 & 5.07 & 1.72 \\
\hline 2 & Non-muscle myosin heavy polypeptide 9 & 227646 & 5.50 & 2.90 \\
\hline 3 & Beta actin & 42052 & 5.29 & 1.96 \\
\hline 4 & Vimentin & 53710 & 5.06 & 1.97 \\
\hline 5 & Vimentin & 53710 & 5.06 & 2.22 \\
\hline 6 & Beta 5-tubulin & 50095 & 4.78 & 2.59 \\
\hline 7 & Beta 5-tubulin & 50095 & 4.78 & XA only ${ }^{c}$ \\
\hline
\end{tabular}

Down-regulated proteins

\begin{tabular}{|c|c|c|c|c|}
\hline Spot No. ${ }^{a}$ & Protein name $e^{b)}$ & MW (Da) & $\mathrm{pI}$ & $\begin{array}{l}\text { Ratio of spot volume } \\
\text { (xanthoangelol/control) }\end{array}$ \\
\hline 8 & KH-type splicing regulatory protein & 73458 & 6.84 & 0.64 \\
\hline 9 & Peroxiredoxin 6 & 25133 & 6.00 & 0.56 \\
\hline 10 & Triosephosphate isomerase 1 & 26938 & 6.45 & 0.59 \\
\hline 11 & DJ-1 & 20050 & 6.33 & 0.37 \\
\hline 12 & Glyceraldehyde-3-phosphate dehydrogenase & 36201 & 8.57 & 0.60 \\
\hline 13 & Splicing factor 2 & 27842 & 10.37 & 0.52 \\
\hline 14 & Eukaryotic translation elongation factor 1 beta 2 & 28900 & 4.50 & 0.65 \\
\hline 15 & Phosphoglycerate mutase 1 & 24919 & 6.67 & 0.57 \\
\hline 16 & Phosphoglycerate dehydrogenase & 57356 & 6.29 & 0.63 \\
\hline
\end{tabular}

a) The protein spots indicated in Fig. 3A were analyzed using MALDI-TOF-MS. b) Proteins were identified using MASCOT with a custom human ORF database obtained from NCBI. c) The spot was detected only in xanthoangelol-treated group.

A

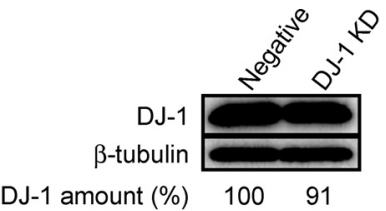

$\mathrm{B}$

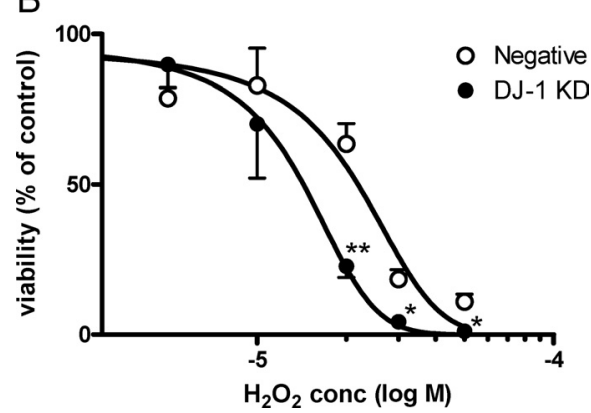

Fig. 4. Sensitivity to Oxidative Stress Damage in DJ-1-Knocked Down Neuroblastoma Cells

(A) DJ-1 protein amount from whole extract of DJ-1-knocked down IMR-32 cells or negative control cells was analyzed by Western blotting. Percentage of DJ-1 amount was calculated from the ratio of band densities (DJ-1/ $\beta$-tubulin). (B) Cell viability in response to oxidative stress was determined by trypan blue exclusion assay in DJ-1knocked down IMR-32 cells $(\bullet)$ and negative control cells $(\bigcirc)$ using Stealth RNAi Vertical axis indicates the viability against each control group which was treated with RNAi and without $\mathrm{H}_{2} \mathrm{O}_{2}$ exposure (mean \pm S.E.M.; $n=3 ; * p<0.05, * * p<0.01 \mathrm{com}$ pared to negative control by Student's $t$-test).

production of ROS increases and/or when the antioxidants decreases. Recent studies have shown that ROS acts as a second messenger in apoptosis. Generation of ROS induces mitochondrial cytochrome $\mathrm{c}$ release, in which sequential activation of caspase- 9 and caspase-3 occurs. ${ }^{19)}$ To clarify whether xanthoangelol triggers oxidative stress, we measured xanthoangelol-induced ROS generation. As expected, ROS was generated immediately after application of xanthoangelol at
$10 \mu \mathrm{M}$ and $100 \mu \mathrm{M}$, and it markedly increased within $30 \mathrm{~min}$ (Fig. 5A). At both concentrations, the levels of ROS continued to increase by $120 \mathrm{~min}$ and showed a 5.6-fold and 2.8fold increase at $10 \mu \mathrm{M}$ and $100 \mu \mathrm{M}$, respectively, compared to the control at $120 \mathrm{~min}$ (Fig. 5A). Increase of ROS by xanthoangelol was also observed in SK-N-SH, NB-39 and LA$\mathrm{N}-1$ neuroblastoma cell lines (data not shown). On the other hand, the levels of ROS were not increased by xanthoangelol in cell-free medium (data not shown). Fluorescence microscopy showed intracellular accumulation of ROS in IMR32 cells treated by $10 \mu \mathrm{M}$ xanthoangelol for $1 \mathrm{~h}$ (Fig. 5Bd), but not in control preparations (Fig. $5 \mathrm{Bb}$ ). These findings indicate that xanthoangelol increases the level of intracellular ROS by acting on the cell rather than as the oxidant itself. Moreover, we examined whether this ROS generation was inhibited by a major lipid-soluble antioxidant, VE, which plays a role in protecting cellular membranes from oxidative stress. Pretreatment with VE dramatically inhibited xanthoangelolinduced ROS production (Fig. 5C). The generation of ROS was not affected by treatment with VE alone (Fig. 5C). In contrast, the generation of ROS by xanthoangelol was not prevented by a water-soluble antioxidant, $N$-acetyl-L-cysteine (data not shown). Since xanthoangelol-induced ROS was markedly inhibited by VE, we next examined whether VE prevents xanthoangelol-induced cell death. As shown in Fig. $5 \mathrm{D}, \mathrm{VE}$ completely prevented xanthoangelol-induced cell death, whereas it did not inhibit cisplatin-induced cell death. In addition, almost all of the cells treated with $10 \mu \mathrm{M}$ xanthoangelol for $24 \mathrm{~h}$ exhibited nuclear condensation (Fig. $5 \mathrm{~Eb}$ ), whereas $\mathrm{VE}$ pretreatment reduced the number of cells exhibiting this feature (Fig. 5Ec). VE alone had no effect on cell viability or morphology upon comparison with normal cells (Fig. 5D, Figs. 5Ea, d). These results demonstrate that oxidative stress on the cellular membrane plays a critical role 


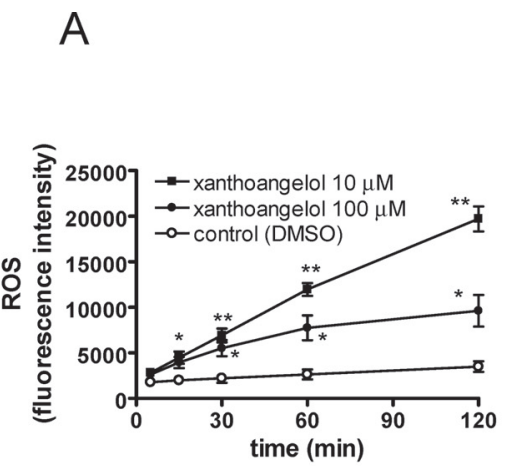

B
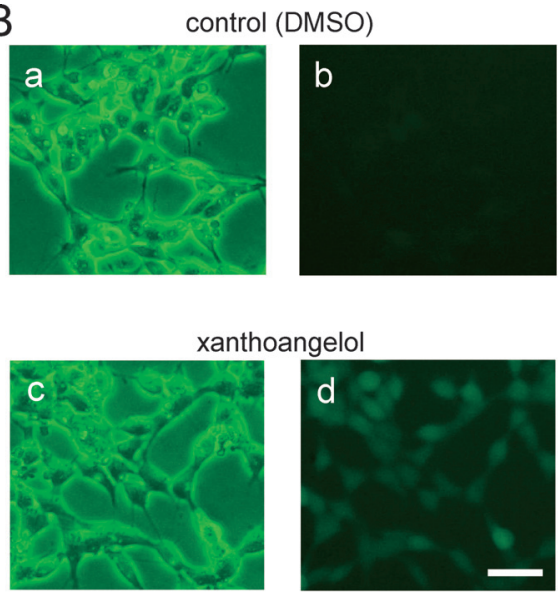

C

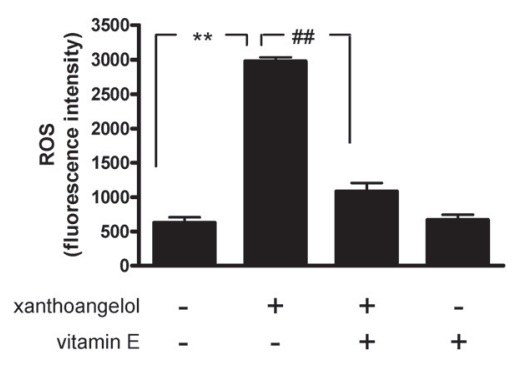

$\mathrm{D}$
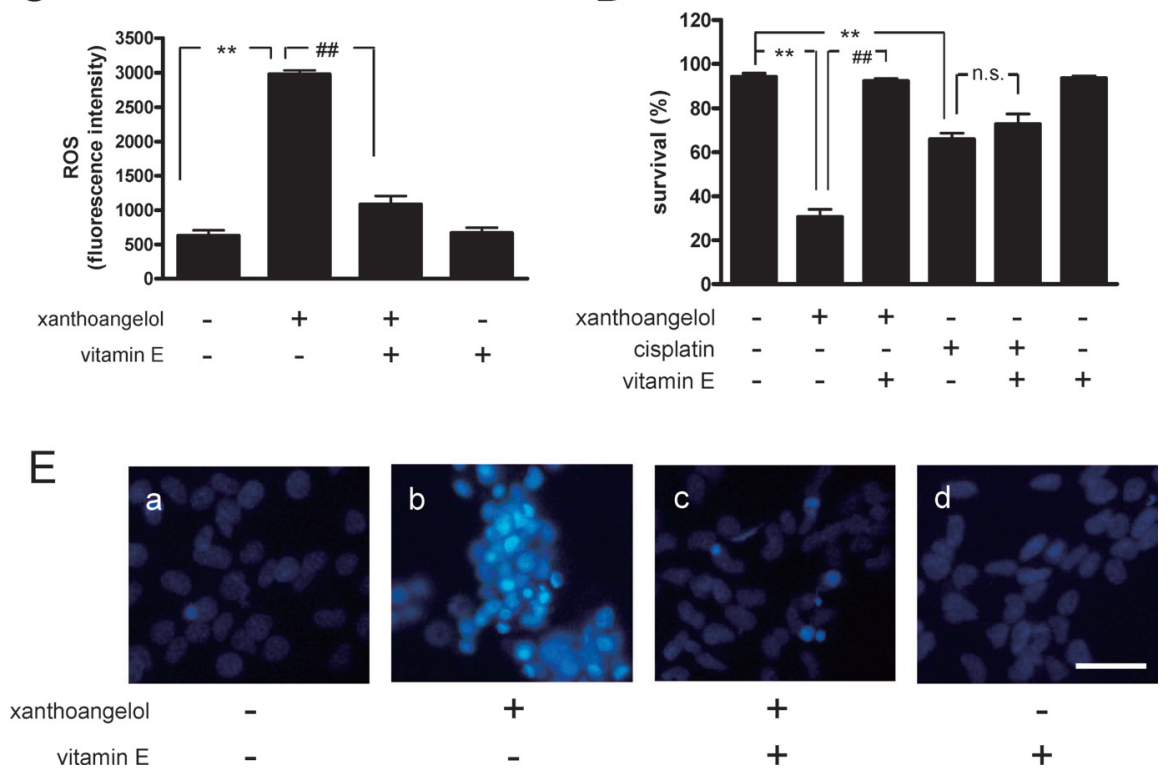

Fig. 5. ROS Generation Is Essential for Xanthoangelol-Induced Apoptosis

(A) Generation of ROS was measured with $\mathrm{H}_{2}$ DCFDA dye using a fluorescence microplate reader. IMR-32 cells were treated with $10 \mu \mathrm{M}(\mathbf{\square})$ and $100 \mu \mathrm{M}(\bullet)$ xanthoangelol or DMSO (control; O) for 5, 15, 30, 60, $120 \mathrm{~min}$. Each plot shows the fluorescence intensity (mean \pm S.E.M.; $n=3$ ). $* p<0.05$, $* * p<0.01 v s$. control compared by one-way ANOVA followed by Bonferroni's post-hoc test. (B) Intracellular ROS in IMR-32 cells at $2 \mathrm{~h}$ after treatment with $10 \mu \mathrm{M}$ xanthoangelol (xanthoangelol; c and d) or DMSO (control; a and b) was observed by fluorescence microscopy. Left panels (a and c) and right panels (b and d) show the phase contrast image and the fluorescent image, respectively. Phase contrast and fluorescent images were obtained from the same view. Bar, $20 \mu \mathrm{m}$. (C) IMR-32 cells were treated with $10 \mu \mathrm{M}$ xanthoangelol or vehicle for $2 \mathrm{~h}$ in the presence or absence of $1 \mathrm{~mm}$ vitamin E, and ROS was measured using $\mathrm{H}_{2}$ DCFDA dye. Each column shows fluorescence intensity (mean \pm S.E.M.; $n=3$ ). $* * p<0.01 v s$. normal cells, \# $p<0.01 v s$. xanthoangelol alone compared by one-way ANOVA followed by Bonferroni's post-hoc test. (D) Cell viability was determined by trypan blue exclusion test. IMR-32 cells were pretreated with $1 \mathrm{~mm}$ vitamin $\mathrm{E}$ or vehicle for $3 \mathrm{~h}$, and then treated with $10 \mu \mathrm{M}$ xanthoangelol, $10 \mu \mathrm{M}$ cisplatin or vehicle for $24 \mathrm{~h}$. Each column shows survival rate (mean \pm S.E.M.; $n=3$ ). $* * p<0.01 v s$. normal cells, \#p<0.01 vs. xanthoangelol alone, n.s. (not significant) compared by one-way ANOVA followed by Bonferroni's post-hoc test. (E) Nuclear morphology was observed by fluorescence microscopy using Hoechst 33342 dye. IMR-32 cells were pretreated with 1 mM vitamin E (c and d) or ethanol (a and b), then treated with $10 \mu \mathrm{M}$ xanthoangelol (b and c) or DMSO (a and d) for $24 \mathrm{~h}$. Bar, $20 \mu \mathrm{M}$.

in xanthoangelol-induced apoptosis.

\section{DISCUSSION}

Our results demonstrate that the mitochondrial pathway plays an important role in xanthoangelol-induced apoptosis in neuroblastoma. Conventional therapeutic DNA-damaging agents that induce p53- and caspase-9-dependent mitochondrial apoptosis are often used for treatment of neuroblastoma. ${ }^{20}$ It has been reported that LA-N-1 neuroblastoma cells are resistant to such chemotherapeutic agents because they have no functional p53 protein due to a mutation causing a stop codon. ${ }^{21,22)}$ In agreement with this, we showed that LA-N-1 cells were resistant to camptothecin and cisplatin.
Xanthoangelol, on the other hand, had a cytotoxic effect on drug-resistant neuroblastomas. Thus, the mechanism of xanthoangelol-induced cell death appears to be distinct from that of cisplatin-induced p53-dependent cell death. Since NB-39 cells were also resistant to camptothecin and cisplatin, we speculate that p53 protein is inactivated in the NB-39 cell line. However, there has been no report of p53 abnormalities in the NB-39 cell line. Some other factors may be involved in the mechanism of drug resistance. The expressions of brainderived neurotrophic factor (BDNF) and its receptor TrkB protect cells from cisplatin-induced death ${ }^{23)}$ and are associated with biologically aggressive neuroblastoma. ${ }^{24)}$ Moreover, high levels of multidrug-resistance-associated protein 1 (MRP1)/ABCC1 are predictive of poor outcome in neuro- 
blastoma. ${ }^{25)}$ Whatever the mechanism, overcoming drug resistance is an important approach for treatment of advanced neuroblastoma.

We demonstrated the profile of proteins changed by xanthoangelol treatment in IMR-32 cells for the first time using proteomic analysis. Most of the changed proteins were involved in oxidative stress: DJ-1, peroxiredoxin 6, triosephosphate isomerase 1, glyceraldehyde-3-phosphate dehydrogenase and phosphoglycerate mutase 1 . The 2-DE experiment demonstrated that the amount of DJ-1 protein in the spot was prominently decreased by xanthoangelol. However, no change in the total amount of DJ-1 was observed at $1 \mathrm{~h}$ of xanthoangelol treatment using immunoblotting. DJ-1 has been reported to show a shift of $\mathrm{pI}$ from basic to acidic by being oxidized itself when cells are treated with oxidative stress inducers such as hydrogen peroxide $\left(\mathrm{H}_{2} \mathrm{O}_{2}\right)$ and ultraviolet radiation. ${ }^{16-18)}$ The acidic form of DJ-1 was dramatically increased at $30 \mathrm{~min}$ after application of xanthoangelol. In parallel with this, there was an abrupt increase of ROS at $30 \mathrm{~min}$. Therefore, this $\mathrm{pI}$ shift of DJ-1 indicates an oxidative stress status. Peroxiredoxin 6 was also decreased by xanthoangelol. Since peroxiredoxin 6 is also an oxidative stressresponsive protein that oxidizes itself, ${ }^{16)}$ it is possible that peroxiredoxin 6 shows a pI shift like that of DJ-1. Glycolytic enzymes including triosephosphate isomerase 1, glyceraldehyde-3-phosphate dehydrogenase and phosphoglycerate mutase 1 were decreased by xanthoangelol treatment. The activity of glycolytic enzymes decreases during exposure to $\mathrm{H}_{2} \mathrm{O}_{2}$, leading to production of NADPH to maintain the redox balance. $^{26)}$ The decrease in the protein levels of glycolytic enzymes seems to be for protection against oxidative stress induced by xanthoangelol. Moreover, expression of GRP78/ $\mathrm{BiP}$, an endoplasmic reticulum (ER) chaperone, was up-regulated by xanthoangelol. It is likely that ER stress is also involved in xanthoangelol-induced apoptosis. Thus, complex mechanisms are responsible for xanthoangelol-induced apoptosis. In the experiment designed to investigate ROS, the levels of ROS were more highly increased by xanthoangelol at $10 \mu \mathrm{M}$ than at $100 \mu \mathrm{M}$. This also implies that xanthoangelolinduced apoptosis was not entirely dependent on ROS generation. However, oxidative stress plays a crucial role in this mechanism because xanthoangelol triggered ROS accumulation and the antioxidant VE completely prevented apoptosis induced by xanthoangelol.

DJ-1 was first identified as a novel oncogene cooperating with $\mathrm{H}-\mathrm{ras},{ }^{27)}$ and recently it has attracted interest as a causative gene for familial Parkinson's disease. ${ }^{28)}$ Several studies have shown that DJ-1 acts as an antioxidant protein. DJ-1-knockdown cells and cells expressing mutant forms of DJ-1 found in Parkinson's disease patients are more sensitive to oxidative stress, whereas overexpression of wild-type DJ-1 suppresses such oxidative stress-induced cell death. ${ }^{18,29)}$ In the present study, we showed that DJ-1 was decreased at 8 and $24 \mathrm{~h}$ after treatment with xanthoangelol, and that this event was temporally related to caspase- 9 activation. Moreover, DJ-1 knock down cells were more sensitive to oxidative stress damage. These results imply that a decrease of DJ-1 leads to loss of its function and to acceleration of oxidative stress and apoptosis. During oxidative stress conditions, DJ-1 scavenges oxidants by being oxidized itself. ${ }^{16,18)}$ Moreover, it has been reported that DJ-1 reduces the level of cellular ROS by activating phosphatidylinositol 3-kinase (PI3K)/Akt survival signaling. ${ }^{30)}$ Elevated levels of DJ-1 have been reported in breast, prostate and lung cancer, and this abnormal cell survival is due to DJ-1-promoted PI3K/Akt signaling. ${ }^{31-33)}$ Thus, down-regulation of DJ-1 could be a new strategy for development of cancer therapeutic drugs.

In this study, we have revealed the mechanism of xanthoangelol-induced apoptosis. Xanthoangelol induces mitochondria-mediated apoptosis via oxidative stress through accumulation of ROS and down-regulation of DJ-1. Through this mechanism, xanthoangelol can overcome drug-resistant neuroblastoma. Neuroblastoma cells are sensitive to buthionine sulfoximine and fenretinide, which induce oxidative stress. $^{34,35)}$ Indeed, fenretinide has been used in a clinical trial for neuroblastoma. ${ }^{35)}$ It has also been reported that increasing the level of ROS or inhibition of antioxidants can be used to target cancer cells, and that drugs capable of doing this show selective toxicity against cancer cells compared with normal cells. $^{36,37)}$ Taken together, the present findings suggest that apoptotic induction of oxidative stress is effective against neuroblastoma. However, further in vivo experiments are required to determine the physiological effect, pharmacokinetic concentration and bioavailability of xanthoangelol. If these studies on animal model can be achieved, this agent would be therapeutically advantageous for treatment of advanced neuroblastoma.

Acknowledgements Grant support: This work was supported by the "Academic Frontier" Project for Private Universities: matching fund subsidy from MEXT (Ministry of Education, Culture, Sports, Science and Technology) 20022006.

\section{REFERENCES}

1) Nakagawara A., Nakamura Y., Ikeda H., Hiwasa T., Kuida K., Su M. S., Zhao H., Cnaan A., Sakiyama S., Cancer Res., 57, 4578-4584 (1997).

2) Oue T., Fukuzawa M., Kusafuka T., Kohmoto Y., Imura K., Nagahara S., Okada A., J. Pediatr. Surg., 31, 251-257 (1996).

3) Castle V. P., Heidelberger K. P., Bromberg J., Ou X., Dole M., Nunez G., Am. J. Pathol., 143, 1543-1550 (1993).

4) Keshelava N., Zuo J. J., Chen P., Waidyaratne S. N., Luna M. C., Gomer C. J., Triche T. J., Reynolds C. P., Cancer Res., 61, 6185-6193 (2001).

5) Hopkins-Donaldson S., Bodmer J.-L., Bourloud K. B., Brognara C. B., Tschopp J., Gross N., Cancer Res., 60, 4315-4319 (2000).

6) Akihisa T., Tokuda H., Ukiya M., Iizuka M., Schneider S., Ogasawara K., Mukainaka T., Iwatsuki K., Suzuki T., Nishino H., Cancer Lett., 201, 133-137 (2003).

7) Inamori Y., Baba K., Tsujibo H., Taniguchi M., Nakata K., Kozawa M., Chem. Pharm. Bull., 39, 1604-1605 (1991).

8) Matsuura M., Kimura Y., Nakata K., Baba K., Okuda H., Planta Med., 67, 230-235 (2001).

9) Murakami S., Kijima H., Isobe Y., Muramatsu M., Aihara H., Otomo S., Baba K., Kozawa M., J. Pharm. Pharmacol., 42, 723-726 (1990).

10) Okuyama T., Takata M., Takayasu J., Hasegawa T., Tokuda H., Nishino A., Nishino H., Iwashima A., Planta Med., 57, 242-246 (1991).

11) Kimura Y., Baba K., Int. J. Cancer, 106, 429-437 (2003).

12) Tabata K., Motani K., Takayanagi N., Nishimura R., Asami S., Kimura Y., Ukiya M., Hasegawa D., Akihisa T., Suzuki T., Biol. Pharm. Bull., 28, 1404-1407 (2005).

13) Stennicke H. R., Salvesen G. S., Biochem. Biophys. Acta, 1477, 299 $306(2000)$

14) Danial N. N., Korsmeyer S. J., Cell, 116, 205-219 (2004).

15) Okano S., Shibata Y., Shiroza T., Abiko Y., Proteomics, 6, 251-258 
(2006)

16) Kinumi T., Kimata J., Taira T., Ariga H., Niki E., Biochem. Biophys. Res. Commun., 317, 722-728 (2004).

17) Shinbo Y., Niki T., Taira T., Ooe H., Takahashi-Niki K., Maita C., Seino C., Iguchi-Ariga S. M., Ariga H., Cell Death. Differ., 13, 96108 (2006)

18) Taira T., Saito Y., Niki T., Iguchi-Ariga S. M. M., Takahashi K., Ariga H., EMBO Rep., 5, 213-218 (2004).

19) Ueda S., Masutani H., Nakamura H., Tanaka T., Ueno M., Yodoi J., Antioxid. Redox Signal., 4, 405-414 (2002).

20) Cui H., Schroering A., Ding H. F., Mol. Cancer Ther, 1, 679-686 (2002).

21) Davidoff A. M., Pence J. C., Shorter N. A., Iglehart J. D., Marks J. R., Oncogene, 7, 127-133 (1992).

22) Karlsson J., Øra I., Pörn Ares I., Påhlman S., Clin. Cancer Res., 10, 3179-3188 (2004).

23) Ho R., Eggert A., Hishiki T., Minturn J. E., Ikegaki N., Foster P., Camoratto A. M., Evans A. E., Brodeur G. M., Cancer Res., 62, 6462-6466 (2002).

24) Nakagawara A., Azar C. G., Scavarda N. J., Brodeur G. M., Mol. Cell. Biol., 14, 759-767 (1994).

25) Haber M., Smith J., Bordow S. B., Flemming C., Cohn S. L., London W. B., Marshall G. M., Norris M. D., J. Clin. Oncol., 24, 1546-1553 (2006).

26) Costa V. M. V., Amorim M. A., Quintanilha A., Moradas-Ferreira P., Free Radic. Biol. Med., 33, 1507-1515 (2002).

27) Nagakubo D., Taira T., Kitaura H., Ikeda M., Tamai K., Iguchi-Ariga
S. M., Ariga H., Biochem. Biophys. Res. Commun., 231, 509—513 (1997).

28) Bonifati V., Rizzu P., van Baren M. J., Schaap O., Breedveld G. J., Krieger E., Dekker M. C., Squitieri F., Ibanez P., Joosse M., van Dongen J. W., Vanacore N., van Swieten J. C., Brice A., Meco G., van Duijn C. M., Oostra B. A., Heutink P., Science, 299, 256-259 (2003).

29) Yokota T., Sugawara K., Ito K., Takahashi R., Ariga H., Mizusawa H., Biochem. Biophys. Res. Commun., 312, 1342-1348 (2003).

30) Yang Y., Gehrke S., Haque M. E., Imai Y., Kosek J., Yang L., Beal M. F., Nishimura I., Wakamatsu K., Ito S., Takahashi R., Lu B., Proc. Natl. Acad. Sci. U.S.A., 102, 13670-13675 (2005)

31) Grzmil M., Voigt S., Thelen P., Hemmerlein B., Helmke K., Burfeind P., Int. J. Oncol., 24, 97-105 (2004).

32) Kim R. H., Peters M., Jang Y., Shi W., Pintilie M., Fletcher G. C., DeLuca C., Liepa J., Zhou L., Snow B., Binari R. C., Manoukian A. S., Bray M. R., Liu F. F., Tsao M. S., Mak T. W., Cancer Cell, 7, $263-$ 273 (2005).

33) Le Naour F., Misek D. E., Krause M. C., Deneux L., Giordano T. J., Scholl S., Hanash S. M., Clin. Cancer Res., 7, 3328-3335 (2001).

34) Anderson C. P., Tsai J. M., Meek W. E., Liu R. M., Tang Y., Forman H. J., Reynolds C. P., Exp. Cell Res., 246, 183-192 (1999).

35) Reynolds C. P., Matthay K. K., Villablanca J. G., Maurer B. J., Cancer Lett., 197, 185-192 (2003).

36) Huang P., Feng L., Oldham E. A., Keating M. J., Plunkett W., Nature (London), 407, 390-395 (2000).

37) McLachlan A., Kekre N., McNulty J., Pandey S., Apoptosis, 10, 619630 (2005). 